\title{
Impact of Industry 4.0 on Environmental Sustainability
}

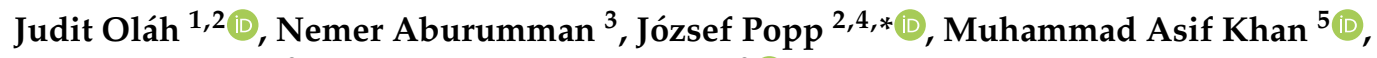 \\ Hossam Haddad ${ }^{3}$ and Nicodemus Kitukutha ${ }^{3}$ (D) \\ 1 Institute of Applied Informatics and Logistics, Faculty of Economics and Business, University of Debrecen, \\ 4032 Debrecen, Hungary; olah.judit@econ.unideb.hu \\ 2 TRADE Research Entity, North-West University, Vanderbijlpark 1900, South Africa \\ 3 Károly Ihrig Doctoral School of Management and Business, University of Debrecen, \\ 4032 Debrecen, Hungary; nemer.aburumman@econ.unideb.hu (N.A.); \\ haddad_hossam@hotmail.com (H.H.); nicodemus.kitukutha@econ.unideb.hu (N.K.) \\ 4 Faculty of Economics and Social Sciences, Szent Istvan University, 2100 Gödölő, Hungary \\ 5 University of Kotli, Azad Jammu and Kashmir, Faculty of Management Sciences, Department of Commerce, \\ City Kotli 11100, Pakistan; khanasif82@uokajk.edu.pk \\ * Correspondence: popp.jozsef@gtk.szie.hu; Tel.: +36-302973163
}

Received: 9 May 2020; Accepted: 2 June 2020; Published: 8 June 2020

\begin{abstract}
Industry 4.0 is a concept that originated from the German industry, and whose essence is the use of technology for efficient production. In business today, the emergence of Industry 4.0 for production, and its related technologies, such as the Internet of Things (IoT) and cyber-physical systems, amongst others, have, however, a negative impact on environmental sustainability as a result of air pollution, the poor discharge of waste, and the intensive use of raw materials, information, and energy. The method used in this study is an analysis of a literature review of manuscripts discussing topics related to Industry 4.0 and environmental sustainability published between 2000 and 2020. There is currently a gap existing between the actual and the desired situation, in that production occurs in a weak sustainability model, and, therefore, this research debates the effects on environmental sustainability and the challenges facing Industry 4.0. Four scenarios are discussed: a deployment scenario, an operation scenario, integration and compliance with sustainable development goals, and a long-run scenario. The results indicate that there is a negative relationship related to the flow of the production process from the inputs to the final product, including raw materials, energy requirements, information, and waste disposal, and their impacts on the environment. However, the integration of Industry 4.0 and the sustainable development goals enhance environmental sustainability to create ecological support that guarantees high environmental performance with a more positive impact than before. This paper will help stakeholders and companies to provide solutions to the existing environmental challenges that can be mediated through adopting new technologies. The novelty of this study is its depiction of Industry 4.0 and its technologies integrated with sustainable development goals to create a sustainable Industry 4.0 combining environmental protection and sustainability.
\end{abstract}

Keywords: Industry 4.0; environment; sustainability; impact; sustainable development; sustainability

\section{Introduction}

Industrialization is a vital process in production. Many organizations that have not adopted information technology (IT) are struggling to survive. In business today, regardless of their sectors and activities, entities have the same view concerning the future and do not want to be taken by surprise. Therefore, every sector is adopting Industry 4.0 due to the capabilities of the quality achieved in product customization. However, with Industry 4.0 there is still a high consumption of resources, raw materials, information, and energy, which is environmentally unsustainable despite numerous advantages of 
Industry 4.0 and this has made society and the public sector more aware and concerned about the risks and environmental challenges [1]. Therefore, this paper seeks to improve the conditions of this sector and to help it become not just economically better but environmentally and socially sustainable.

This sector of industrialization with the use of Industry 4.0 has focused mainly on production and achieving the highest profits, and this has created many problems for other dimensions. For example, the depletion of natural resources, negative impacts on the environment, unequal distribution of wealth, and inappropriate conditions of work, all of which may eventually lead to an unsustainable consumption pattern environmentally, economically, and even socially [2]. In the production system, in the context of environmental sustainability, there are limitations to ensure that natural resources are used at a constant rate not exceeding the rate of renewal of these resources, and the environmental capacity to absorb these wastes should not be ignored. The focus should be on renewable natural resources as alternatives to non-renewable ones [3]. Production occurs in a "weak sustainability" model, which means the rational exploitation of natural resources or even the minimization of waste to match what is environmentally disposable.

However, despite all of the above, and even though consumers are aware of the limited nature of resources and their importance, we are still a long way from sustainable consumption, and the demand for goods and products is much higher than real needs; there is, therefore, a great difference between sustainable consumption and actual behavior [4]. Considering the current situation, the sector encourages production and profit while ignoring other factors that will lead to diminishing limited and unlimited resources, and hence to climate instability, and serious impacts on the environment, as well as biodiversity loss [5,6]. From previous studies, we have noted the importance of the environmental aspects mentioned earlier, and that the use of Industry 4.0's modern technology will create greater sustainability and increase the quality of products [7]. However, Industry 4.0 focuses primarily on increasing production and quality so that it can increase revenues and competitiveness. At present, this industrial revolution has focused more on production and not on an environmentally sustainable framework, even considering the many challenges facing this industry such as the unification of regulations, organizational protocols, the search for skilled workers, and the adoption of a compatible legal framework [8]. Industry 4.0 has changed the way businesses and production are conducted in their entirety, in terms of procedures, methods, and practicability $[9,10]$. The cost of Industry 4.0 infrastructure seems to be reasonable when budgeted environmentally, but it is still difficult to predict its direct impact on environmental sustainability [11]. Therefore, the main question is: what is the impact of Industry 4.0 on environmental sustainability and society?

The essential intention of this research was to explain to what extent Industry 4.0 can affect the flow of raw materials, energy, and resources used in production, as well as the waste and residues generated after the adoption of Industry 4.0 technologies, and whether all of these will have a negative or positive impact on environmental sustainability in the final analysis. In doing so, this paper will provide a better understanding of the accompanying impacts and thus help stakeholders and governments to adopt policies that are best suited to the ideal reflected in the adoption of these technologies $[10,12]$. According to the scenario approach, the methodology examined the literature involving manuscripts on the topic of Industry 4.0 and environmental sustainability. In addition, it used secondary data. This was to test the effects of Industry 4.0 on environmental sustainability. Data were analyzed for justifications, and a description was made of each type. Subsequently, the impact of Industry 4.0 on organizations' operational scenarios was also investigated. Besides, negative and positive impacts on sustainability were studied to depict their trends. Furthermore, Industry 4.0 attributes which offer a conceivable chance of integration with the sustainable development goals (SDGs) to create greater environmental sustainability were investigated, to provide advice on policies that can align these two sectors so that they can work in harmony and create higher benefits for stakeholders. There was a prediction those good opportunities could be tapped and be beneficial in the long-term if this is worked out well. The only thing lacking was good policies that support the implementation of all these structures; and the conclusion was that the current adoption of Industry 4.0 would lead to 
environmental sustainability. Therefore, policies on environmental sustainability will serve as the backbone of Industry 4.0. Firstly, an analysis should be carried out to determine how inputs of raw materials, information, and energy can be controlled. Secondly, as the production takes place, there will be refined and quality products and at the same time byproducts; can these be used as raw materials again? Thirdly, upon completion of the production process, how can waste be treated before disposal in a way that can reduce air pollution through emissions of harmful gases and contaminated water and ground, and which in return can be fed back into the generation of natural resources? Finally, policies need to be put in place for the ecosystem to have the opportunity to regenerate itself, to achieve co-existence.

In the introduction, we have presented a wide discussion of Industry 4.0 and its technologies that enhance smart production, while in the literature review we have used 116 published articles to depict the key areas analyzed by other researchers and disclose the gap that necessitates our study. In the materials and methods section, the literature review is used with the papers from 2000 to 2020 on Industry 4.0. In the results, interpretations, and conclusions, policies are been emphasized as the key for a sustainable future.

\section{Literature Review}

\subsection{Industry 4.0 and Its Technologies}

This section will introduce the main concepts related to Industry 4.0, starting with a general background and then moving on to the concept of Industry 4.0 and the definition of the basic terminologies accompanying it; at the end of this section, we will describe the characteristics that will emerge from the use of these techniques, including the capabilities and functions created as a result of them. However, Industry 4.0 is a complex topic. Its complexity needs to be analyzed from three perspectives: functional, structural, and qualitative [13]. Also, these complexities can be manifested in both natural and technological settings, and always affect the level of understanding in the system that we are studying and the quality of decision-making within it [14].

The term Industry 4.0 has become a common term recently and was specifically mentioned in a German government initiative in 2011 to be a strategy for industrial production in that country [15]. According to this vision, Industry 4.0 is part of an integrated and interconnected world that has evolved through the information and communication technology (ICT) revolution. This technological change in Industry 4.0 occurs through the Internet of things (IoT) and the Internet of Services (IOS), which connect industry through a supply chain network internally and externally in an electronic way. This makes industry "smart", and all this is supported by cyber-physical systems (CPSs). The CPS discussed in this text can be defined as systems where hardware and software parts are interconnected to yield results on a large scale $[15,16]$. A literature review with a systematic approach to Industry 4.0 deals with energy efficiency, and its concerns and challenges $[17,18]$. Hence, we can see that Industry 4.0 is a major component of CPS and IoT. Previous studies have shown different concepts of Internet-related Industry 4.0 such as the Internet of services (IOS), the Internet of Everything (IOE), and the Internet of People (IOP). Industry 4.0 includes a range of technologies alongside IOE and CPS, such as big data, cloud computing, additive manufacturing (3D printing) [19], and blockchain [20].

CPSs connect the physical elements of the industry, such as machines and other components, to an electronic layer of information systems through sensors and other devices. This technology allows the exchange of information, conducts procedures, and becomes an interconnector between humans and machines. The Internet of things (IoT) is a new term [21] defined as association by the Internet of the physical world which is equipped and outfitted with sensors, and actuators. Through this connection, all signals from the physical production system can be monitored and recorded as "big data" for later use in other processes such as creating new value, especially in the context of changing demand for innovative services [22] and new forms of employment [23]. One of the technologies used in the fourth industrial revolution is "cloud computing" which [24] is defined as computing 
resources and services of visualization, which is a mixture of innovation and application of new technologies like Industry 4.0 that create a meaningful and gainful impact on organizations' operations to cut costs and create efficiency. Finally, integration of all forms of existing technologies with the physical elements in manufacturing with all related stockholders (suppliers, customers, consumers, and employees) creates many advantages for Industry 4.0, such as automation and digitization [25]. This helps decision-making because the information is available in a complete way, which limits the institutional hierarchy.

Therefore, Industry 4.0 provides new features and possibilities in manufacturing in two main aspects: the value added to the final customer and production process capabilities. We have collected the most notable advantages that we have found in the literature in Table 1.

Table 1. Advantages of Industry 4.0 to the final customer (value-added) and for companies' production process capabilities.

\begin{tabular}{|c|c|}
\hline Added Value to Consumers & Additional Values to Companies \\
\hline Enhanced customization [26-28]. & Improved efficiency $[26,27]$. \\
\hline Better customer experience [29]. & Boosted synergy (when the structure is decoupled into \\
\hline Knowledge sharing increased among them [30]. & subsystems with very little interdependence) [32]. \\
\hline Changing needs of consumers supported [31]. & \\
\hline Reduced cost [33]. & Enhanced integration through data flow, thus promoting a \\
\hline Easier compliance [34]. & more flexible structure and data \\
\hline Quality products, hence a high standard of living [31]. & swap among all the elements [2]. \\
\hline Job opportunities created [35]. & $\begin{array}{l}\text { Improved productivity and efficiency, opportunity creation } \\
\text { through innovation, flexibility, and agility }[36,37] \text {. }\end{array}$ \\
\hline $\begin{array}{l}\text { The advent of novel business models which allow new } \\
\text { ways of value creation; according to reference [28], } \\
\text { these are cloud-based, service-oriented } \\
\text { process-oriented business models [38]. }\end{array}$ & $\begin{array}{l}\text { Intelligent learning analysis promoted, which allows devices } \\
\text { and machines to develop learning capacities and act in } \\
\text { response to different situations based on previous } \\
\text { experiences [39]. }\end{array}$ \\
\hline $\begin{array}{l}\text { End-to-end numeral integration, allowing the } \\
\text { integration of business processes across the entire value } \\
\text { chain, including the factory floor and services using } \\
\text { CPSs [40]. }\end{array}$ & $\begin{array}{l}\text { Simulated and modeled impacts of process-steps; the } \\
\text { possibility to design and test new plants before setting up by } \\
\text { virtualization [41]. }\end{array}$ \\
\hline
\end{tabular}

Source: Authors' own editing (2020). CPSs—cyber-physical systems.

\subsection{Sustainable Environment and Industry 4.0}

The sustainability of the environment in Industry 4.0 is an important topic and has been largely addressed in the previous literature. Although the previous literature represents different views on this relationship, there is no clear consensus that Industry 4.0 has a long-term impact on environmental sustainability [11]. Therefore, this paper focuses on environmental sustainability, and we will address studies that focus on dimensions that are particularly related to this. Other studies argue that start-ups and new companies included their strategies and vision on integrating Industry 4.0 and production with environmental sustainability. Studies by Ford and Despeisse [42] and Jelonek and Urbaniec [43] showed the benefits of adopting technology in manufacturing (such as 3D printing) for environmental sustainability but also revealed the presence of several challenges because the technology is still at an immature stage. On the other hand, Stock and Seliger [44] have argued that industrial value should be sustainability-oriented and Industry 4.0 provides tremendous opportunities to achieve this sustainability. In another study, the authors surveyed some German and Chinese companies to study the expected impacts of Industry 4.0 on environmental sustainability, with the environmental dimension linked through several factors: energy efficiency and resources. According to Burritt and Christ [45], environmental sustainability is positively impacted by Industry 4.0 through comprehensive digitization that provides more accurate, high-quality management and real-time event management for the external environment.

In another study by Müller and Hopf [46], the authors propose a model based on the triple bottom line (TBL), which is a model that includes the challenges and opportunities associated with the application of Industry 4.0; the authors conclude that there is an important and positive relationship 
between the application of Industry 4.0 and its environmental benefits so that companies tend to adopt this technology more given its benefits and regardless of the company size and industry sector. In other studies, Tim et al. [47] and Müller and Hopf [46] have proposed a roadmap aimed to promote the optimal and sustainable use of natural resources by promoting circular economy principles in organizations in an Industry 4.0 approach to the recycling of waste, which is positive for the environment.

Junior et al. [48] investigated the relationship between environmental protection and process safety variables within Industry 4.0 by exploring the existence of the common keyword in previous literature and found that there is more research linked to environmental protection and Industry 4.0 than literature relating to Industry 4.0 and process safety [49]. In other studies, Junior et al. [48], Carrillo et al. [50], and Lingam [29] have found that value creation contributes positively to sustainable development through new processes and the creation of a life cycle perspective [51] and new business models. In a study by Kumar and Luthra [52], the authors identified 18 challenges that Industry 4.0 can face when developing the sustainability of the supply chain.

Finally, we reviewed several previous literature strands linking Industry 4.0 and environmental sustainability. In summary, previous studies have used different approaches to address the subject, including exploratory studies by Ford and Despeisse [42]; interviews with specialists or experts in the field [28]; content analysis and statistical data; adoption of resource efficiency indexes for environmental sustainability assessment; indexes of efficiency for materials, water, energy, and quantity waste [43,53,54]; environmental costs [33,55]; and environmental impact reduction [55]. In conclusion, after reviewing all these studies, the challenges and opportunities associated with the implementation of Industry 4.0 are still uncertain, and the technologies associated with this industry in terms of environmental sustainability have not been adequately explored because these are still new technologies. Therefore, a gap still exists on how to integrate the efficient use of scarce resources, raw materials, information, responsible consumption, and energy with sustainable development goals in long-term solutions. To reduce pollution in the environment and achieve sustainability, the 4 Rs-reduce, reuse, recycle, and replace - can be used. Hence, efficiency and eco-innovation will be realized in Industry 4.0 and the environment. This is a new finding, in addition to other the authors' contributions.

\section{Materials and Methods}

To address the problem of Industry 4.0 and environmental sustainability we studied and analyzed theoretical and literature reviews by different authors. Our study included a literature review, and the method used was to collect all the manuscripts on the topic of Industry 4.0 related to environmental sustainability published between 2000 and 2020. Secondary data was also used. This enabled us to examine the positive and negative impacts of Industry 4.0 on the manufacturing sector and its primary technology from an environmental sustainability perspective. In order to obtain a holistic conception, we first went through the production system, i.e. the raw materials, energy, and information needed to process inputs into outputs to obtain products, as well as the waste and end life products, and greenhouse gas (GHG) emissions. This is illustrated in more detail in Figure 1. 


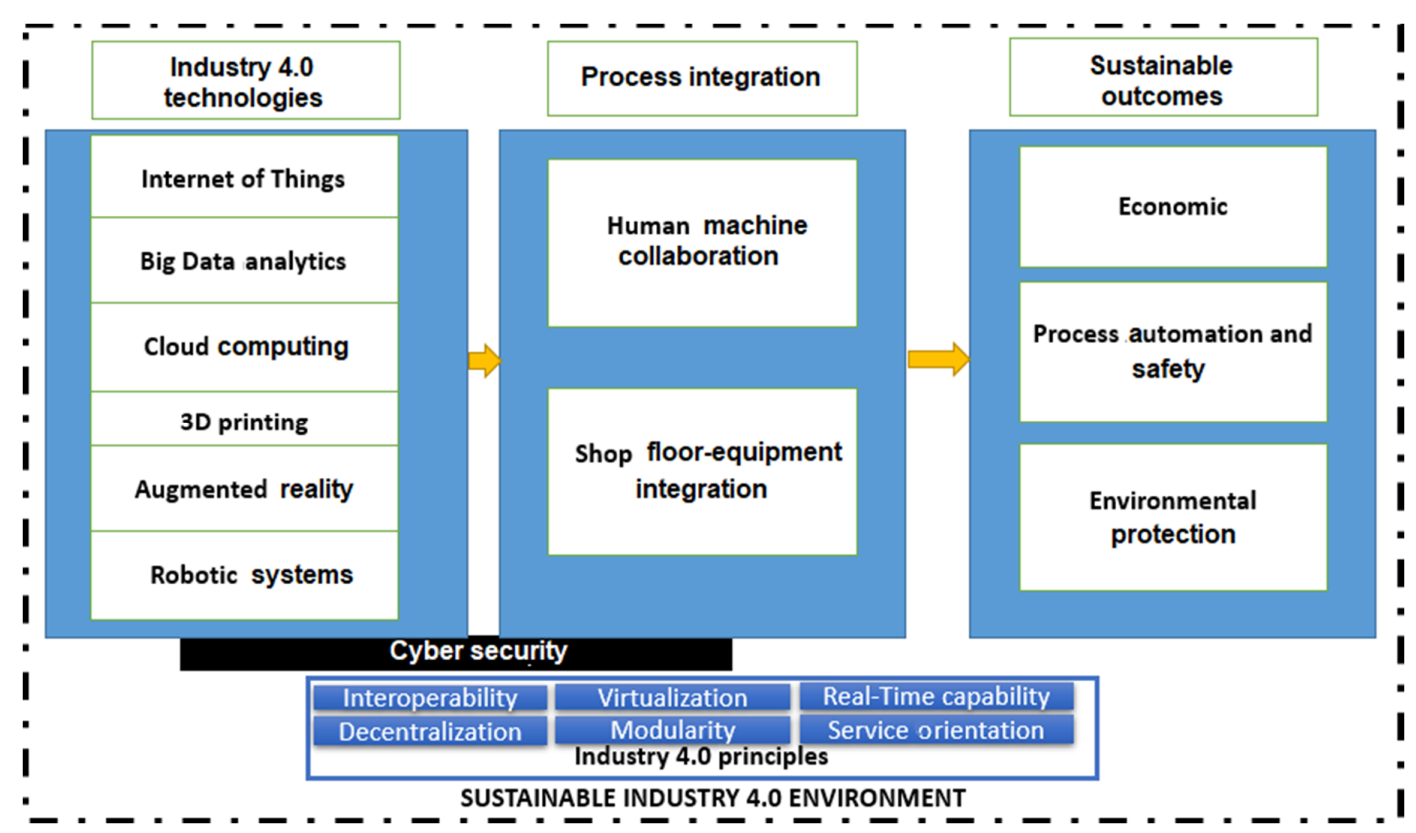

Figure 1. The setup of Industry 4.0, its technologies, processes of integration, and sustainable outcomes that lead to environmental sustainability and protection. Source: Authors' own editing (2020).

\section{Results}

\subsection{Scenario Analysis}

The scenario we refer to is a set of conditions that influence environmental sustainability either positively or negatively. In Industry 4.0, inputs such as raw materials, energy, and information go through several stages of production and, consequently, needs and opportunities emerge. The description here appeared in the literature review in terms of the flow of the objects in the production process and any modification(s) that will affect environmental sustainability. In this regard, a scenario-based analysis was used to examine the environmental impact in terms of sustainability. This included, for example, the use of sustainable energy in production, and at the same time, attempts to recycle output waste for better consumption, as has been illustrated in previous research studies. We studied the benefits of Industry 4.0 concerning environmental sustainability in the four scenarios, as follows in Table 2.

Table 2. Scenario stages illustrating positive or negative environmental sustainability impacts.

\begin{tabular}{cccc}
\hline Deployment Scenario & Operation Scenario & SDGs Relation Scenario & Long-Term Scenario \\
\hline Digitization [2] & Real-time data & Renewable energy & Decrease $(-)$ \\
Integration [2] & Customization & Innovative infrastructure & Increase (+) \\
Automation [2] & Smart production & Responsive consumption & Decrease $(-)$ \\
\hline
\end{tabular}

Source: Authors' own editing (2020). SDGs—sustainable development goals.

Figure 2 explains how all the scenarios are foreseen from the production stage, and the operation stage integrated with SDGs, to achieve environmental sustainability using Industry 4.0. 


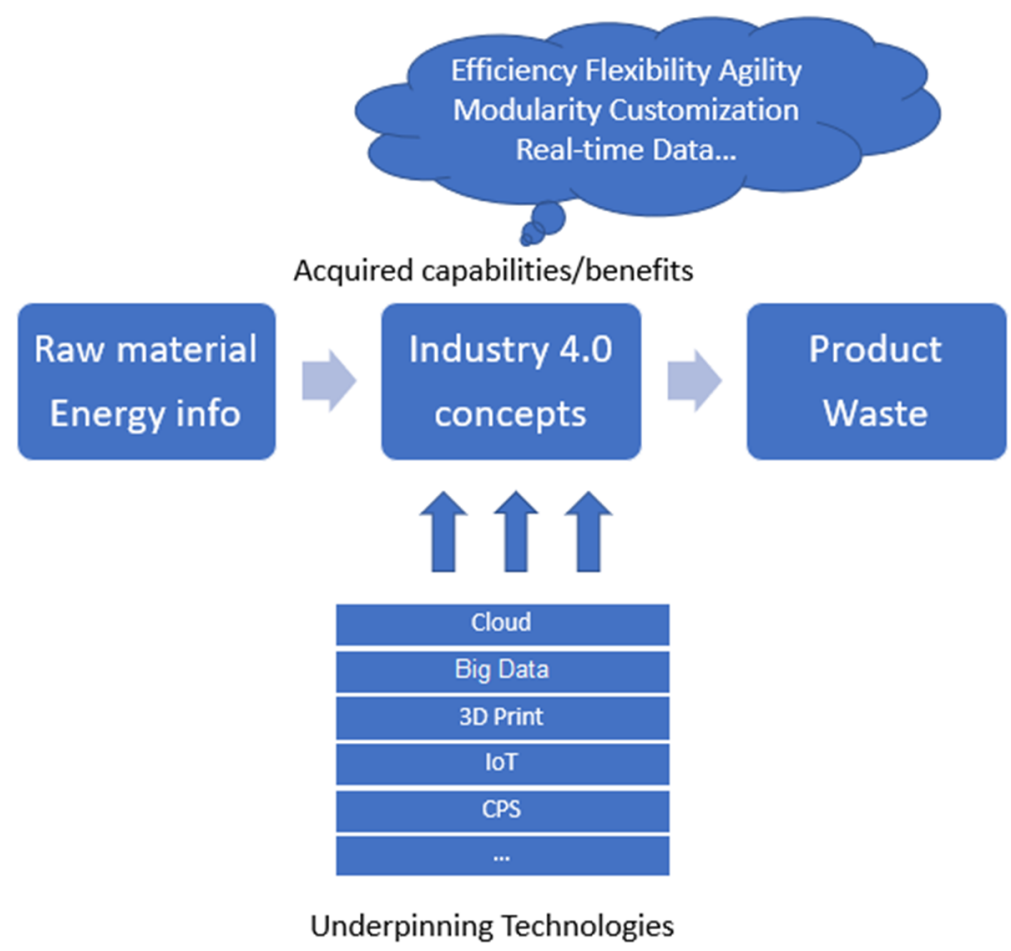

Figure 2. Setup of an approach to deployment and operation with SDGs to obtain long-term sustainability for. Source: Authors' own editing (2020). IoT-Internet of things.

The below is the model of the operation in Industry 4.0 and references from custimazation to efficiency shows how the deployment and operation with SDGs are integrated to obtain long sustainability both in the Industry 4.0 and environment in theoretical and framework analysis.

Modality customization [19]

Real-time data [56]

Raw material energy information [2]

Industry 4.0 concepts [57]

Product waste [58]

Cloud [59]

Big Data, 3D printing [60]

Internet of Things [59]

Cyber physical systems [25]

Efficiency flexibility agility [36]

Source: Authors' own editing (2020). IoT-Internet of things.

Deployment Scenario

Without a doubt, the effects of Industry 4.0 and its benefits are evident. Smart production [61], real-time data, and automation are some examples of these positive effects. However, Industry 4.0 is still faced with environmental sustainability challenges. The infrastructure required to enable Industry 4.0 to be operational is highly demanding of new machines, software, and hardware, which might be very costly at the beginning, although in the long run, the benefits will outweigh the costs. In the production process, energy is required for the transformation of inputs to outputs. However, emissions of $\mathrm{SO}_{2}$ and $\mathrm{CO}_{2}$ are released, which are toxic, so a solution is required to avoid health problems. The impact of Industry 4.0 on environmental sustainability will be shown in Table 3 below. 
Table 3. Impacts of Industry 4.0 on environmental sustainability in terms of the demand for inputs.

\begin{tabular}{cccc}
\hline Industry 4.0 & Attention/Action & Effects Flow & Impact on Environment \\
\hline \multirow{4}{*}{ Automation [2] } & Need for new equipment & More materials required & Negative \\
& & More energy required & Negative \\
& Obsolete equipment & Disposal or recycled & Negative \\
& More fuel to transport & Negative \\
Digitization [2] & New device required & More materials required & Negative \\
& & More energy required & Negative \\
& Obsolete equipment & Disposal or recycled & Negative \\
& New device required & More energy required & Negative \\
& & More material required & Negative \\
Integration [2] & Disposal or recycled & Negative \\
& Obsolete equipment & More material required & Negative \\
& & Disposal or recycled & Negative \\
\hline
\end{tabular}

Source: Authors' own editing (2020).

Table 4 shows the expected operational scenario needs of the Industry 4.0 technology framework impacts on the flow of energy, based on the literature.

Table 4. The requirements of Industry 4.0 in the operational scenario.

\begin{tabular}{lll}
\hline & \multicolumn{2}{c}{ Requirements of Industry 4.0 } \\
\hline \multirow{2}{*}{ Industry 4.0 [49]. } & \multicolumn{1}{c}{ Smart production } & \multicolumn{1}{c}{ Production and customization } \\
\cline { 2 - 3 } & $\begin{array}{l}\text { Internet of things and CPS integration } \\
\text { [59].Real-time data control [56]. }\end{array}$ & $\begin{array}{l}\text { On-demand production and } \\
\text { customization [19]. }\end{array}$ \\
Needs [2]. & Needs massive data [62]. & Dynamic configuration processes [56]. \\
Flows [2]. & Energy flows increase [63]. & Needs massive data [62]. \\
Trend [2]. & Negative impact [35]. & Negative impact [35]. \\
\hline
\end{tabular}

Source: Authors' own editing (2020).

Table 5 shows how Industry 4.0 offers and creates opportunities throughout its operation, and we can observe the effect of the cause-effect impacts on the relevant flows.

Table 5. The effect of the cause-effect positive impacts on the relevant flows.

\begin{tabular}{|c|c|c|c|}
\hline Elements & Opportunities & Effects & Impact \\
\hline $\begin{array}{l}\text { Smart production [64]. } \\
\text { The integration }\end{array}$ & Vertical [65]. & $\begin{array}{l}\text { Material and energy flow } \\
\text { [2]. }\end{array}$ & + \\
\hline \multirow[t]{3}{*}{ of real-time data control [2]. } & Horizontal [66]. & Material and energy use [67]. & + \\
\hline & Collection data [68]. & Subjectively by customers & + \\
\hline & Material consumption [42]. & Decreased flow of materials [67]. & + \\
\hline \multirow[t]{2}{*}{ Data analytics [68]. } & Energy consumption [42]. & Decreased energy [67]. & + \\
\hline & Maintenance [68]. & Decreased energy [67]. & + \\
\hline Additive manufacturing [69-71]. & $\begin{array}{l}\text { Prototyping [19]. } \\
\text { Tool and shape manufacturing [72]. } \\
\text { Final item manufacturing [73]. } \\
\text { Part industrialization [74]. }\end{array}$ & $\begin{array}{l}\text { Decreased waste [67]. } \\
\text { Decreased flow of materials [67]. } \\
\text { Decreased waste [67]. } \\
\text { Decreased fluids and forging. } \\
\text { Increase energy [75]. }\end{array}$ & $\begin{array}{l}+ \\
+ \\
+ \\
+ \\
-\end{array}$ \\
\hline $\begin{array}{l}\text { On-demand production and } \\
\text { customization }[57,76] \text {. }\end{array}$ & $\begin{array}{l}\text { Elimination of the undesired } \\
\text { products [69]. }\end{array}$ & Decreased material and energy [67]. & + \\
\hline & Disruptive business model [77]. & The extended life cycle of products [75]. & + \\
\hline Blockchain technology $[78,79]$. & $\begin{array}{l}\text { Transparency/decentralization/reliable } \\
\text { information [78]. }\end{array}$ & Increased energy flows [75]. & \\
\hline
\end{tabular}

Source: Authors' own editing (2020).

Table 6 shows the integration of the approaches between the SDGs and Industry 4.0 elements and the opportunities for improvement that emerge from that integration. After reviewing many works in the literature, we concur with Bonilla et al. [2] that if good use is made of Industry 4.0, it can be well integrated with the sustainable development goals, which can result in efficiency and the effective use of non-renewable and renewable resources [65]. 
Table 6. Benefits of integrating SDGs with Industry 4.0 to enhance environmental sustainability.

\begin{tabular}{|c|c|c|c|c|c|c|c|}
\hline SDG & 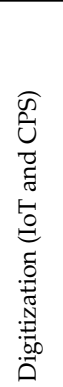 & 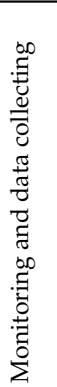 & 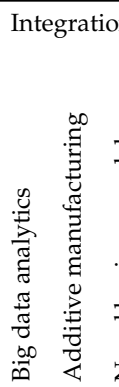 & 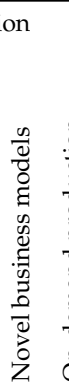 & 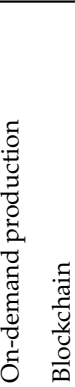 & $\begin{array}{l}\text { Enhanced Opportunities towards } \\
\text { Environmental Sustainability }\end{array}$ & Effect on Flows \\
\hline SDG 7 & $\sqrt{ }$ & $\sqrt{ }$ & $\sqrt{ }$ & & & $\begin{array}{l}\text { Implementation of smart grids [36]. } \\
\text { Implementation of life cycle assessments [80]. }\end{array}$ & $\begin{array}{l}\text { Decreased energy flows [2]. } \\
\text { Increased renewable energy [81]. }\end{array}$ \\
\hline SDG 9 & $\sqrt{ }$ & $\sqrt{ }$ & $\sqrt{ }$ & $\sqrt{ }$ & & $\begin{array}{l}\text { Improvement of weak points of additive } \\
\text { manufacturing (energy and recyclability) [2]. } \\
\text { Extended integration with the circular economy [2]. }\end{array}$ & $\begin{array}{l}\text { Decreased energy flows [2]. } \\
\text { Decreased material flows [2]. } \\
\text { Decreased waste flows [2]. } \\
\text { Decrease end-of-life products [36]. }\end{array}$ \\
\hline SDG 12 & $\sqrt{ }$ & $\sqrt{ }$ & & & $\sqrt{ }$ & $\begin{array}{l}\text { Production of reliable and transparent } \\
\text { sustainability reports, on Industry } 4.0 \text { in } \\
\text { manufacturing sector [2]. }\end{array}$ & $\begin{array}{l}\text { Increased reliable data [82]. } \\
\text { Decreased material flows [2]. } \\
\text { Decreased waste flows [36]. }\end{array}$ \\
\hline SDG 13 & $\sqrt{ }$ & $\sqrt{ }$ & $\sqrt{ }$ & & $\sqrt{ }$ & $\begin{array}{l}\text { Implementation of smart grids [82]. } \\
\text { Implementation of life cycle assessments [83]. } \\
\text { Blockchain-enabled emissions trading [20]. }\end{array}$ & $\begin{array}{l}\text { Decreased energy flows [2]. } \\
\text { Increased renewable energy [70]. } \\
\text { Decreased GHG emission [51]. }\end{array}$ \\
\hline
\end{tabular}

Source: Authors' own editing (2020). GHG—greenhouse gas. 
Table 7 below illustrates the benefits realized in the long run, when all the stakeholders come together to overcome challenges of Industry 4.0 and turn them into opportunities for investors.

Table 7. The optimistic and pessimistic long-term scenarios, according to the key factors.

\begin{tabular}{lll}
\hline \multicolumn{1}{c}{ Key Factor } & $\begin{array}{l}\text { Response } \\
\text { Optimistic }\end{array}$ & Pessimistic \\
\hline Device demand [2]. & Increased recycling [84]. & $\begin{array}{l}\text { Increased raw materials flow in the } \\
\text { fabrication [2]. }\end{array}$ \\
$\begin{array}{l}\text { Consumer concerns [2]. } \\
\text { Company infrastructure [2]. }\end{array}$ & $\begin{array}{l}\text { More awareness of sustainability [85]. } \\
\text { Homogeneity in terms of automation and } \\
\text { digitization [86]. }\end{array}$ & $\begin{array}{l}\text { Heterogeneity in terms of automation } \\
\text { and digitization [24]. }\end{array}$ \\
Spatially homogeneous adoption of the & $\begin{array}{l}\text { Spatially homogeneous adoption of } \\
\text { the technology [2]. }\end{array}$ \\
& $\begin{array}{l}\text { technology [2]. } \\
\text { Exchange of technology between }\end{array}$ & $\begin{array}{l}\text { Technology concentrated in } \\
\text { developed countries [88]. }\end{array}$ \\
Equipment obsolescence [2]. & - & $\begin{array}{l}\text { Increased flows of products to be } \\
\text { disposed of, recycled [2]. }\end{array}$ \\
& - & $\begin{array}{l}\text { Increased fuel for transportation } \\
\text { (towards disposal or recycling) [89]. }\end{array}$ \\
Novel business models [2]. & $\begin{array}{l}\text { Promote value co-creation } \\
\text { Promote pro-environmental markets [77]. }\end{array}$ \\
Unskilled workforce [2]. & $\begin{array}{l}\text { Focus on training and formation [90]. } \\
\text { Research substitutes [91]. }\end{array}$ & - \\
Raw material demand [2]. & - & - \\
\hline
\end{tabular}

Source: Authors' own editing (2020).

In the long term, Industry 4.0 will rely heavily on public choices, social responses, legal structure, and homogenous distribution. Sustainability will be heterogeneously distributed between countries with different digitalization levels, which will lead to niches of non-sustainability patterns and inequality. Nevertheless, the table below shows how these challenges can be converted to opportunities by adopting Industry 4.0, which leads to sustainability and enhances policymaking.

Table 8 shows the benefits of Industry 4.0 that outweigh its challenges to sustainability.

Table 8 . The benefits of Industry 4.0 outweigh the challenges to sustainability.

\begin{tabular}{|c|c|c|}
\hline Industry 4.0 Disadvantages & Industry 4.0 Advantages & Industry 4.0 Sustainability \\
\hline Capital [44]. & Customization [19]. & Robotic-assisted production [22]. \\
\hline Security [59]. & Optimization [84]. & $\begin{array}{l}\text { Big-data-driven quality control } \\
\text { [59]. }\end{array}$ \\
\hline Privacy [92]. & Pushing research [56]. & Product line simulation [66]. \\
\hline Staff education [93]. & Vertical networking [94]. & Predictive maintenance [68]. \\
\hline Reluctance to adopt Industry 4.0 [95]. & Horizontal networking [94]. & Self-driven logistics vehicles [29]. \\
\hline Data ownership [37]. & Engineering entire value chain [22]. & $\begin{array}{l}\text { A machine as a tool to high } \\
\text { efficiency in production [57]. }\end{array}$ \\
\hline
\end{tabular}

Source: Authors' own editing (2020).

However, an explanation should be given here. It should be noted that sustainability is a broad concept; therefore, flows chosen to address environmental sustainability have already been used elsewhere [37]. When an event is implemented, calculations of flow patterns will become simpler. Nonetheless, the positive effect of activities on the flows is highly dependent on the production quantity. When production increases, flows will also increase and there will be a transformation of negative impacts into positive trends by adopting an e-commerce environmental sustainability dimension. Table 9 shows the advantages and disadvantages of Industry 4.0 and environmental sustainability. 
Table 9. Industry 4.0 and environmental sustainability pros and cons.

\begin{tabular}{|c|c|c|}
\hline Dimension & Advantages & Disadvantages \\
\hline \multirow{9}{*}{ Environment } & Flexibility and integration of production [56]. & Costly to adopt and manage [90]. \\
\hline & $\begin{array}{l}\text { Increased use of smart gadgets (IoT) Industry } \\
4.0 \text { [91]. }\end{array}$ & Technical skills required [96]. \\
\hline & $\begin{array}{l}\text { Efficient production increases economic } \\
\text { stability and sustainability [57]. }\end{array}$ & High pollution of the environment [92]. \\
\hline & $\begin{array}{l}\text { Large markets with the better financial } \\
\text { performance [56]. }\end{array}$ & Interference of the ecosystem [93]. \\
\hline & Ensures quality products [31]. & Disposal of the waste harmful to society [69]. \\
\hline & $\begin{array}{l}\text { High revenue through vertical and horizontal } \\
\text { integration [30]. }\end{array}$ & $\begin{array}{l}\text { Minimum compliance with regulations and } \\
\text { laws by companies [97]. }\end{array}$ \\
\hline & $\begin{array}{l}\text { Industry } 4.0 \text { has reduced production time } \\
\text { hence efficiency [37]. }\end{array}$ & $\begin{array}{l}\text { The intensity of Industry } 4.0 \text { has led to } \\
\text { deforestation [82]. }\end{array}$ \\
\hline & Customization and digitization [77]. & Health-related diseases [98]. \\
\hline & $\begin{array}{l}\text { Corporate social responsibility is undertaken } \\
\text { by companies towards consumers [ } 42]\end{array}$ & Ground and water service contamination [96]. \\
\hline
\end{tabular}

Source: Authors' own editing (2020).

\section{Discussions}

\subsection{Environment Sustainability}

First, we would like to mention that the environment provides scarce and limited natural resources. Consequently, it is of great importance to focus our attention on the fact that sustainability is extremely important, not only for companies but also for the community and economic growth dimensions [99]. Without conserving and protecting these resources, sooner rather than later companies will have no raw materials to use in production. The ideal situation of environmental sustainability is where natural resources can regenerate themselves and be used without compromising the life cycle of production. This cannot be quantified in terms of measurement in scale but an increase or decrease in sustainability. Bonilla et al. [2] stated that it will be possible to quantify environmental sustainability by moving towards a distant goal from the ideal point of sustainability to achieve not only sustainable production but also consumption. With this in mind, we measured sustainability impacts by determining whether there was an increase or decrease towards a sustainable state that integrates and supports the United Nations sustainable development goals (SDGs) [100]. In this case, we attempted to use relevant parameters that would give direct meaning to our scenarios. As a result, our purpose was not to measure indicators or quantify them, but rather use a systematic approach and exploration perspective. This provides an easy understanding of the topic without ambiguous and complex procedures to determine how to ensure the sustainability of the environment.

Goodland and Daly [101] carried out a comparison and came up with interesting examples that can be used to measure performance in sustainability systems. Through these studies, we found connections and parameters that had similar characteristics that are desirable for this measurement. According to Habbard [102], a business strategy to ensure environmental sustainability must factor in the following parameters: the performance of companies and the environment. These desirable characteristics allow us to determine whether there was a direct relationship or a cause-effect relationship, simply because it is easy to use, handle, examine, and control internal and external interference.

To determine the influence of Industry 4.0 on environmental sustainability, we investigated the four scenarios in manufacturing activities. Due to a lack of literature on sustainability in the environment and Industry 4.0, we carried out a cross-section study from different authors' analyses to be able to get a good basis for an evaluation and determination of the sustainability concept. Through the literature, we identified that the digitization of industrial production will positively influence environmental sustainability, as such factors of resources and consumption will be efficiently utilized, as was found in the results of German and Chinese companies in the survey undertaken by Beier et al. [53] of green manufacturing technology as one of the benefits of Industry 4.0, among many others. 
Current technologies in Industry 4.0 produce a cause-effect relationship in the manufacturing industry and help activities that are related to environmental sustainability. Breaking down scenarios into smaller categories made the process of detecting the requirements and needs that will become evident in the future much easier. Moreover, the opportunities that appeared after filtering Industry 4.0 components can be captured in more detail in the results tables. Therefore, when comparing scenarios one and two with each other, various implementation techniques were studied. According to the results, the application of Industry 4.0 would lead to fewer negative impacts and more positive impacts in terms of the use of materials, energy, information, and high-quality products. Various degrees of adherence to the SDGs' fundamentals were investigated while comparing scenarios two and three, which is of great importance. Through the results, it was noted that SDGs numbers 7, 9, 12 , and 13 were more suited to our topic of discussion. This was because affordable clean energy and responsible consumption are elements of sustainability methods. Developing industries that are efficient and can protect the planet against climate change is the priority of everyone on Earth, to ensure our survival. In scenario 4, results showed a temporal prognosis with two different and opposing trends, i.e., SDGs support all the operations and ensure environmental sustainability can be enhanced through integration. Therefore, to attain long-term sustainability integration is the main objective.

As demonstrated by comparing scenarios one and two, environmental sustainability trends were stage-dependent. At the deployment stage, the trend was said to be negative, while the operational stage turned positive. Supporting policies and inventions will be required to increase the possibility of converging Industry 4.0 technologies to the SDGs' platforms. Industry 4.0 will transform opportunities to proactive responses if it is integrated with the SDGs, but to establish good environmental performance well-established eco-innovation should be used in this integration. When properly prepared, environmental sustainability will be provided with a higher range of opportunities by means of the functionalities developed.

For Industry 4.0 to be realized, three stages must take place: digitization, automation, and integration. During the production process, there is wear and tear on machines, and at a certain point in time machines become obsolete and must be replaced with new ones. In addition, there is a high level of consumption and use of raw materials and energy. The environment is on the receiving end where waste is concerned. Recycling must take place, and therefore, to avoid a negative environmental impact, recycling is highly encouraged, and more energy-saving will be achieved. This creates a win-win solution for policymakers, factory managers, governments, and organizations and will ensure environmental sustainability.

With Industry 4.0, the operation scenario represents the predictable status quo and how it affects the raw materials needed for energy consumption, storage, data collection, and analysis. The operation of Industry 4.0 has developed and exceeded the expected level. It is automatically linked and shares the information and data of the system and is smart enough to predict and preserve machines and maintain them to monitor the production process and manage interdependently a decentralized factory system [103]. It is decisive for Industry 4.0 to gather an enormous amount of information and examine it, and to achieve an ideal performance with sophisticated processes [37]. The Internet of things (IoT) was of importance in obtaining data on energy consumption on a real-time basis. To get better energy efficiency, there are six benefits of adopting and integrating the Internet of things with Industry 4.0 in the manufacturing sector [74]. By using the application to save energy, software tools can be optimized, which means a 30\% reduction in energy consumption [104]. Factories and enterprises can utilize smart energy allocation by using horizontal integration. Intelligent optimization algorithms are used to optimize energy consumption to save energy in production and management through the data processes platform [69]. Real-time data monitoring shows the consumption of resources and responds to production management. Moreover, the evolution of new technologies will help factories to save on the use of materials with the adoption of additive manufacturing (3D printing) [103]. Layer-by-layer additive manufacturing is effective and more efficient and is less wasteful of resources than conventional subtractive methods. 
Suspicions might be raised because of the diversity of results connected with energy efficiency when compared with other approaches to production, i.e., other than Industry 4.0. [44]. Additive manufacturing processes are still inefficient uses of energy and need further investigation. To sustain lifespans, spare parts are produced and there is a set of varying end-of-life practices in additive manufacturing processes $[49,89,105]$. The techniques of additive manufacturing have a positive impact on maintenance and logistics. Using this method, transport is decentralized, hence fuel and energy are saved, and carbon emissions are reduced $[25,106]$. Big data analysis could extend the useful life of the machinery and reduce waste by using preventive and predictive maintenance [49]. Customizing products to meet demand is one of the main factors of Industry 4.0 development. There are two main methods related to the sustainability of the environment. The integration of Industry 4.0 with blockchain technology may allow a redesign of business models among industries by keeping and creating records and implementing contracts [79].

Rising energy consumption appears as a problem and must be dealt with in this scenario. This can be achieved by using the algorithms and data analysis that was provided to optimize energy use, but still, the main challenge is consumption, which should be solved to reach environmental sustainability. The scenario elements have mainly positive impacts on environmental sustainability, at least partially.

Table 6 represents the integration of the approaches between the SDGs and Industry 4.0 elements and the opportunities for improvement that emerge from that integration. It can be noticed that the focus on one of the four approaches of the SDGs will create synergic or multiple responses for all the four methods. For example, two major elements were added when selling tangible products: accessibility and functionality $[44,53,59]$.

\subsection{The Long-Term Scenario}

For management and business, Industry 4.0 will increase sustainable value and make them very competitive, even with all the challenges and risks experienced nowadays [28,46].

Trends in the future will change and have positive impacts experienced by companies and industries of different sizes worldwide if Industry 4.0 is adopted. Environmental sustainability will not be affected directly by Industry 4.0 in the future, compared to previous impacts. Governments', industries', businesses', and societies' responses are to ensure policies are implemented to encourage better integration to avoid the increasing gap between developed and developing countries which can be mediated if there is a will from all the stakeholders. Economic backwardness and social deficiencies will occur if Industry 4.0 is not accepted in a homogenous way in different countries. Another matter that should be carefully studied is consumer customization, which will motivate and allow consumers to consume responsibly, especially in the more economically productive societies but also in developing ones [107]. Industry 4.0 influences consumer behavior and human capital development [108]. New materials will be one of the demands and requirements, including new technological devices such as spare parts for machines, sensors, and drones. Moreover, energy and resources will become more concentrated because of the security of data transfer provided by the infrastructure $[24,92,109]$, which will, therefore, obtain control and responsibility for the consumption mechanism.

There is clear evidence that if Industry 4.0 is integrated with the SDGs, environmental sustainability will be promoted. However, negative effects on environmental performance can result if Industry 4.0 and environmental sustainability are not well-aligned [17,42]. Another factor that can alter future responses is the starting point in terms of the structure of industries since these responses can be different according to the country of origin and its development stage [53]. To avoid a pessimistic scenario, business models can be invented in which environmentally friendly products are created [110]. 


\section{Conclusions}

\subsection{Deployment}

The deployment/productivity scenario we encourage and propose will create higher levels of automation in the manufacturing industry which is of great benefit in terms of horizontal and vertical integration and will enable cohesion. Therefore, this is closely correlated with environmental sustainability in the sense that companies offer employees better working conditions, safety is prioritized, and employees can work from their homes [111], which ensures flexibility and a reduction in pollution. Undertaking this integration means more efficiency in energy use, and fewer working hours spent in the factory by workers. Therefore, this will result in low-cost production by Brundage et al. [67], which will impact sustainability by cutting out middlemen and, in return, consumers will buy the products at a cheaper price. Before the test and results, it appeared that the impacts were negative, due to the extensive use of materials, energy, and information, and a poor discharge of waste, but the situation has been transformed into one with more positive impacts. This can be facilitated by the use of big data analytics in Industry 4.0 to produce only what is needed and factoring how the waste can be turned to energy use that does not cause pollution to the environment [112].

\subsection{Operation Scenario}

Operation/quality improvement entails the process of ensuring that there are minimal errors or no defects in the products. Firms deploy quality assurance teams to analyze proactively, and all business processes that might involve inefficiencies are eliminated. This was also supported by Memon et al. [60], who noted that the use of big data analysis helps in the coordination of information, which is an important tool to study the internal and external factors that influence environmental sustainability by reducing negative impacts and increasing positive ones [2]. At this stage, there is a great deal of improvement compared to the ordinary way of doing business and production; Industry 4.0 has created more efficiency. All departments are synchronized with each other and communication takes place through robots used to gather data. There is minimal use of resources, materials, and energy. This is because production is only done on demand and at the right quantity. Wastes from the factory are recycled and converted into materials and what is left is only what cannot be put to another use. Therefore, proper discharge is done by use of the bioeconomy and the circular economy, to avoid weakening the overall economy. Therefore, innovative ways can be integrated to ensure that factories can use waste to feed the energy system, for example, coal-fired plants instead of cutting down forest hence energy efficiency [113].

\subsection{Sustainable Development Goals}

The sustainable development goals related to our topic are numbers $7,9,12$, and 13, i.e., affordable and clean energy; industry, innovation and infrastructure; responsible consumption and production; and climate change. Griggs et al. [100] stated that these SDGs are interconnected with each other and interdependently related and as such influence each other. Therefore, care should be taken to balance them, which will lead to the sustainability of the planet, the global community, and business. Industry, innovation, and infrastructure have emerged to form Industry 4.0 with smart factories carrying out smart production, through innovative methods that encourage the research into and development of technology to enhance efficiency and effectiveness [8]. Companies investing in research and development bring more awareness of sustainable ways of enabling technology to be better reused, reduced, recycled, and replaced, so that effective use of raw materials, information, and energy is encouraged, as is responsible consumption, according to the SDGs. This will avoid the negative effects of climate change by using renewable energy. One of the SDGs is about clean energy and this can be also integrated with Industry 4.0 during the production stage as well as during transportation of the goods to the final consumer. Using biomethane which is seen as a solution to decarbonization, for example. Moreover, it will be an effective policy to deal with social-economic analysis that enables 
waste as a source of energy in the circular economy and sustainable supply chain by the use of big data analytics [1,114].

\subsection{Industry 4.0 for Long-Term Sustainability}

In the following stages and scenarios, we illustrated the inputs in stage one (deployment scenario) using Industry 4.0, which enables automation, digitization, and integration. The conversion of raw materials into products occurs in the second stage (operation scenario) using real-time data and customization, and hence smart production. Stage three is the relationship between Industry 4.0 and the SDGs (renewable energy, innovation and infrastructure, responsible consumption, and climate change) which will ensure long-term sustainability in the long-term scenario, which is the fourth stage.

Even though the goal of this research does not include a quantitative impact assessment, it should be emphasized that the environmental impact is highly dependent on the biophysical resource consumption. However, to attain maximum benefits of Industry 4.0, well laid out policies must be implemented to protect and conserve the environment and its ecosystems from Industry 4.0's negative impacts to energy transition of instrument mix policy formulation [115]. This should be a concern for all stakeholders. Come up with the policies that are in harmony with Industry 4.0 and its technologies as well as energy-saving during production, transportation, and consumption for a sustainable future. The environmental impact concept can be expressed (population, waste, and technology). Proof of positive impacts in qualitative terms has been found using this approach, which is related to the third term. Certain different methodologies, such as material intensity, life cycle analysis, and energy calculations should be adopted for the environmental impact quantitative assessment to study the effect of Industry 4.0 technology. A context and time frame should be identified to be able to adopt such a framework, although this is beyond the scope of our research.

\section{Limitations of the Study}

Due to the complexity of the topic and its importance to future generations, further research is needed, not only into environmental sustainability but also into both social and economic sustainability. In addition to complexity in natural and technological settings which always affects the level of understanding, if we may have missed some critical factors for the system that we are studying and the quality of our decision-making could be affected too. Besides, considering the structural, functional, and qualitative aspects are of great importance [116]. Policymakers would benefit from scenario-based research; they will be able to predict the existence of impacts caused by the reshaping of Industry 4.0 to production systems. However, Industry 4.0 is still evolving and is facing many challenges that need to be studied frequently to avert a negative impact on environmental sustainability.

Every day there is an increase in population and resource consumption, while we neglect the use of technology (Industry 4.0) that can control the situation at a meaningful rate and support sustainability. Much attention has been paid to making a profit while forgetting the conservation of the environment and social aspects. Sustainability cannot be achieved by dealing with one aspect but has three bottom lines. Industry 4.0 is a very important tool that can be used to eliminate the challenges, although if it is not integrated well it can be a disaster.

The future shows that there will certainly be no more resources, as daily consumption and production is increasing at a growing rate. However, recycling, reusing, and reducing can be of great help, if they are well-managed. Therefore, all stakeholders are encouraged to put these 3Rs into practice. Also, the use of technology-i.e., Industry 4.0-is highly encouraged. Further research can be done on the 3Rs employing a scientific methodology. In addition, more funds should be set aside by governments to conduct research and development which will give policymakers an added advantage by getting ahead of the worst scenarios. Another challenge is that since all stakeholders are not able to come together and work as a team, there is a need for improved consultation through training sessions, seminars, and workshops to create awareness. 
Author Contributions: N.K., H.H., M.A.K., and J.O. conceived the ideas and designed the experiments. J.O., M.A.K., and J.P. performed and analyzed the experiments. N.A. and N.K. wrote the paper, while J.P. and J.O. applied analysis tools. All authors have read and agreed to the published version of the manuscript.

Funding: This article was supported by the János Bolyai Research Scholarship of the Hungarian Academy of Sciences. This research was funded by the National Research, Development, and Innovation Fund of Hungary. Project no. 130377 has been implemented with the support provided by the National Research, Development, and Innovation Fund of Hungary, financed under the KH_18 funding scheme.

Conflicts of Interest: All the authors declare no conflicts of interest.

\section{References}

1. McWilliams, A.; Parhankangas, A.; Coupet, J.; Welch, E.; Barnum, D.T. Strategic decision making for the triple bottom line. Bus. Strategy Environ. 2016, 25, 193-204. [CrossRef]

2. Bonilla, S.; Silva, H.; Terra, M.; Franco, G.R.; Sacomano, J. Industry 4.0 and Sustainability Implications: A Scenario-Based Analysis of the Impacts and Challenges. Sustainability 2018, 10, 3740. [CrossRef]

3. Zhu, D.; Zhang, S.; Sutton, D.B. Linking Daly's Proposition to policymaking for sustainable development: Indicators and pathways. J. Clean. Prod. 2015, 102, 333-341. [CrossRef]

4. Terlau, W.; Hirsch, D. Sustainable consumption and the attitude-behaviour-gap phenomenon-causes and measurements towards a sustainable development. Int. J. Food Syst. Dyn. 2015, 6, 159-174. [CrossRef]

5. Seddon, N.; Mace, G.M.; Naeem, S.; Tobias, J.A.; Pigot, A.L.; Cavanagh, R.; Mouillot, D.; Vause, J.; Walpole, M. Biodiversity in the Anthropocene: Prospects and policy. Proc. R. Soc. B Biol. Sci. 2016, 283, 2094. [CrossRef]

6. Szeremlei Keszi, A.; Magda, R. Sustainable Production and Consumption. Visegr. J. Bioeconomy Sustain. Dev. 2015, 4, 57-61. [CrossRef]

7. Xu, L.D.; Xu, E.L.; Li, L. Industry 4.0: State of the art and future trends. Int. J. Prod. Res. 2018, 56, $2941-2962$. [CrossRef]

8. Lentner, C.; Vasa, L.; Kolozsi, P.P.; Zéman, Z. New dimensions of internal controls in banking after the GFC. Econ. Ann. XXI 2019, 176, 38-48. [CrossRef]

9. Shpak, N.; Odrekhivskyi, M.; Doroshkevych, K.; Sroka, W. Simulation of Innovative Systems under Industry 4.0 Conditions. Soc. Sci. 2019, 8, 202. [CrossRef]

10. Shpak, N.; Podolchak, N.; Karkovska, V.; Sroka, W. The influence of age factors on the reform of the public service of Ukraine. Cent. Eur. J. Public Policy 2019, 13, 40-52. [CrossRef]

11. Smith, J.A. Evaluating the contribution of interpretative phenomenological analysis: A reply to the commentaries and further development of criteria. Health Psychol. Rev. 2011, 5, 55-61. [CrossRef]

12. Bertoncel, T.; Erenda, I.; Meško, M. Managerial early warning system as best practice for project selection at a smart factory. Amfiteatru Econ. 2018, 20, 805-819. [CrossRef]

13. Papadimitriou, F. Conceptual modelling of landscape complexity. Landsc. Res. 2010, 35, 563-570. [CrossRef]

14. Li, Y.; Dai, J.; Cui, L. The impact of digital technologies on economic and environmental performance in the context of industry 4.0: A moderated mediation model. Int. J. Prod. Econ. 2020, 229, 1-13. [CrossRef]

15. Ślusarczyk, B. Industry 4.0: Are we ready? Pol. J. Manag. Stud. 2018, 17, 232-248. [CrossRef]

16. Liao, Y.; Deschamps, F.; Loures, E.D.F.R.; Ramos, L.F.P. Past, present and future of Industry 4.0-a systematic literature review and research agenda proposal. Int. J. Prod. Res. 2017, 55, 3609-3629. [CrossRef]

17. Da Silva, F.S.T.; da Costa, C.A.; Crovato, C.D.P.; da Rosa Righi, R. Looking at energy through the lens of Industry 4.0: A systematic literature review of concerns and challenges. Comput. Ind. Eng. 2020, 143, 1-21. [CrossRef]

18. Bertoldi, P.; Mosconi, R. Do energy efficiency policies save energy? A new approach based on energy policy indicators (in the EU Member States). Energy Policy 2020, 139, 1-18. [CrossRef]

19. Zawadzki, P.; Żywicki, K. Smart product design and production control for effective mass customization in the Industry 4.0 concept. Manag. Prod. Eng. Rev. 2016, 7, 102-105. [CrossRef]

20. Fu, B.; Shu, Z.; Liu, X. Blockchain enhanced emission trading framework in fashion apparel manufacturing industry. Sustainability 2018, 10, 1105. [CrossRef]

21. Chan, H.C. Internet of things business models. J. Serv. Sci. Manag. 2015, 8, 552-568. [CrossRef]

22. Wang, C.; Zhou, G.; Zhu, Z. Service perspective based production control system for smart job shop under industry 4.0. Robot. Comput. Integr. Manuf. 2020, 65, 101954. [CrossRef] 
23. Mura, L.; Vlacseková, D. Motivation of public employees: Case study of Slovak teaching and professional staff. Adm. Si Manag. Public 2018, 67-80. [CrossRef]

24. Haug, K.C.; Kretschmer, T.; Strobel, T. Cloud adaptiveness within industry sectors-Measurement and observations. Telecommun. Policy 2016, 40, 291-306. [CrossRef]

25. Nagy, J.; Oláh, J.; Erdei, E.; Máté, D.; Popp, J. The role and impact of industry 4.0 and the internet of things on the business strategy of the value chain-The case of Hungary. Sustainability 2018, 10, 3491. [CrossRef]

26. O'Rielly, K.; Jeswiet, J. Strategies to improve industrial energy efficiency. Procedia Cirp 2014, 15, 325-330. [CrossRef]

27. Lasi, H.; Fettke, P.; Kemper, H.-G.; Feld, T.; Hoffmann, M. Industrie 4.0. Wirtschaftsinformatik 2014, 56, 261-264. [CrossRef]

28. Kiel, D.; Müller, J.M.; Arnold, C.; Voigt, K.-I. Sustainable industrial value creation: Benefits and challenges of industry 4.0. Int. J. Innov. Manag. 2017, 21, 1-6. [CrossRef]

29. Lingam, Y.K. The role of Artificial Intelligence (AI) in making accurate stock decisions in E-commerce industry. Int. J. Adv. Res. Ideas Innov. Technol. 2018, 4, 2281-2286. Available online: https://www.itu.int/dms_ pub/itu-s/opb/gen/S-GEN-ISSUEPAPER-2018-1-PDF-E.pdf (accessed on 5 April 2020).

30. Evers, G.; Chappin, M.M. Knowledge sharing in smart grid pilot projects. Energy Policy 2020, $143,111577$. [CrossRef]

31. Napolitano, F.; Girolami, A.; Faraone, D.; Chaudhry, M.; Braghieri, A. Appearance, consumer liking and preferences of Lucanian 'Soppressata'salami. Meat Sci. 2020, 167, 1-7. [CrossRef]

32. McGee, Z.A.; Jones, B.D. Reconceptualizing the policy subsystem: Integration with complexity theory and social network analysis. Policy Stud. J. 2019, 47, S138-S158. [CrossRef]

33. Gale, R.J.; Stokoe, P.K. Environmental Cost Accounting and Business Strategy. In Handbook of Environmentally Conscious Manufacturing; Springer: Boston, MA, USA, 2001; pp. 119-136.

34. Mazahir, S.; Ardestani-Jaafari, A. Robust global sourcing under compliance legislation. Eur. J. Oper. Res. 2020, 284, 152-163. [CrossRef]

35. Pajula, T.; Behm, K.; Vatanen, S.; Saarivuori, E. Managing the Life Cycle to Reduce Environmental Impacts. In Dynamics of Long-Life Assets; Springer: Cham, Switzerland, 2017; pp. 93-113.

36. Daki, H.; El Hannani, A.; Aqqal, A.; Haidine, A.; Dahbi, A. Big Data management in smart grid: Concepts, requirements and implementation. J. Big Data 2017, 4, 1-19. [CrossRef]

37. Oesterreich, T.D.; Teuteberg, F. Understanding the implications of digitisation and automation in the context of Industry 4.0: A triangulation approach and elements of a research agenda for the construction industry. Comput. Ind. 2016, 83, 121-139. [CrossRef]

38. Wirtz, B.W.; Daiser, P. Business model development: A customer-oriented perspective. J. Bus. Models 2018, 6, 24-44. Available online: https://www.semanticscholar.org/paper/Business-Model-Development\%3A-ACustomer-Oriented-Wirtz-Daiser/a2eaae231d407fad5d5f0cc396d98afd481b0379 (accessed on 5 April 2020).

39. Biagi, F.; Falk, M. The impact of ICT and e-commerce on employment in Europe. J. Policy Modeling 2017, 39, 1-18. [CrossRef]

40. Wan, J.; Yan, H.; Suo, H.; Li, F. Advances in Cyber-Physical Systems Research. KSII Trans. Internet Inf. Syst. 2011, 5, 1891-1908. [CrossRef]

41. Gunal, M.M. Simulation for Industry 4.0: Past, Present, and Future; Springer: Cham, Switzerland, 2019.

42. Ford, S.; Despeisse, M. Additive manufacturing and sustainability: An exploratory study of the advantages and challenges. J. Clean. Prod. 2016, 137, 1573-1587. [CrossRef]

43. Jelonek, M.; Urbaniec, M. Development of sustainability competencies for the labour market: An exploratory qualitative study. Sustainability 2019, 11, 5716. [CrossRef]

44. Stock, T.; Seliger, G. Opportunities of Sustainable Manufacturing in Industry 4.0. Procedia CIRP 40. In Proceedings of the 13th Global Conference on Sustainable Manufacturing-Decoupling Growth from Resource Use, Berlin, Germany, 16-18 September 2011; pp. 536-541.

45. Burritt, R.; Christ, K. Industry 4.0 and environmental accounting: A new revolution? Asian J. Sustain. Soc. Responsib. 2016, 1, 23-38. [CrossRef]

46. Müller, E.; Hopf, H. Competence center for the digital transformation in small and medium-sized enterprises. Procedia Manuf. 2017, 11, 1495-1500. [CrossRef]

47. Tim, S.; Michael, O.; Holger, K. Industry 4.0 as Enabler for a Sustainable Development: A Qualitative Assessment of its Ecological and Social Potential. Process Saf. Environ. Prot. 2018, 118, 254-267. [CrossRef] 
48. Junior, J.A.G.; Busso, C.M.; Gobbo, S.C.O.; Carreão, H. Making the links among environmental protection, process safety, and industry 4.0. Process Saf. Environ. Prot. 2018, 117, 372-382. [CrossRef]

49. Bressanelli, G.; Adrodegari, F.; Perona, M.; Saccani, N. Exploring how usage-focused business models enable circular economy through digital technologies. Sustainability 2018, 10, 639. [CrossRef]

50. Carrillo, J.E.; Vakharia, A.J.; Wang, R. Environmental implications for online retailing. Eur. J. Oper. Res. 2014, 239, 744-755. [CrossRef]

51. Beier, G.; Ullrich, A.; Niehoff, S.; Reißig, M.; Habich, M. Industry 4.0: How it is defined from a sociotechnical perspective and how much sustainability it includes-A literature review. J. Clean. Prod. 2020, 259, 1-13. [CrossRef]

52. Kumar, M.S.; Luthra, S. Evaluating challenges to Industry 4.0 initiatives for supply chain sustainability in emerging economies. Process Saf. Environ. Prot. 2018, 117, 168-179. [CrossRef]

53. Beier, G.; Niehoff, S.; Ziems, T.; Xue, B. Sustainability aspects of a digitalized industry-A comparative study from China and Germany. Int. J. Precis. Eng. Manuf. Green Technol. 2017, 4, 227-234. [CrossRef]

54. Waas, T.; Hugé, J.; Block, T.; Wright, T.; Benitez-Capistros, F.; Verbruggen, A. Sustainability assessment and indicators: Tools in a decision-making strategy for sustainable development. Sustainability 2014, 6, 5512-5534. [CrossRef]

55. Swain, M.; Blomqvist, L.; McNamara, J.; Ripple, W.J. Reducing the environmental impact of global diets. Sci. Total Environ. 2018, 610, 1207-1209. [CrossRef]

56. Pilloni, V. How data will transform industrial processes: Crowdsensing, crowdsourcing and big data as pillars of industry 4.0. Future Internet 2018, 10, 24. [CrossRef]

57. Pereira, A.; Romero, F. A review of the meanings and the implications of the Industry 4.0 concept. Procedia Manuf. 2017, 13, 1206-1214. [CrossRef]

58. Van Loon, P.; Deketele, L.; Dewaele, J.; McKinnon, A.; Rutherford, C. A comparative analysis of carbon emissions from online retailing of fast moving consumer goods. J. Clean. Prod. 2015, 106, 478-486. [CrossRef]

59. Dang, L.M.; Piran, M.; Han, D.; Min, K.; Moon, H. A survey on internet of things and cloud computing for healthcare. Electronics 2019, 8, 768. [CrossRef]

60. Memon, M.A.; Soomro, S.; Jumani, A.K.; Kartio, M.A. Big Data Analytics and Its Applications. Ann. Emergy Technol. Comput. 2017, 1, 45-54. [CrossRef]

61. Kang, H.S.; Lee, J.Y.; Choi, S.; Kim, H.; Park, J.H.; Son, J.Y.; Kim, B.H.; Do Noh, S. Smart manufacturing: Past research, present findings, and future directions. Int. J. Precis. Eng. Manuf. Green Technol. 2016, 3, 111-128. [CrossRef]

62. Ghani, U.; Monfared, R.; Harrison, R. Real Time Energy Consum. Anal. Manuf. Syst. Using Integr. Virtual Discret. Event Simul. 2012, 69-73. Available online: https://pdfs.semanticscholar.org/7773/ 3ff79c15862825fdfdb6a9d424985b914b37.pdf (accessed on 6 April 2020).

63. Dao, V.; Langella, I.; Carbo, J. From green to sustainability: Information Technology and an integrated sustainability framework. J. Strateg. Inf. Syst. 2011, 20, 63-79. [CrossRef]

64. Sarkar, M.; Sarkar, B. How does an industry reduce waste and consumed energy within a multi-stage smart sustainable biofuel production system? J. Clean. Prod. 2020, 262, 1-12. [CrossRef]

65. Zhou, Y.M.; Wan, X. Product variety and vertical integration. Strateg. Manag. J. 2017, 38, 1134-1150. [CrossRef]

66. Topleva, S. Industry 4.0: Transforming Economy Through Value Added. Asian J. Econ. Model. 2018, 6, 37-46. [CrossRef]

67. Brundage, M.P.; Chang, Q.; Arinez, J.; Xiao, G. Reducing Costs in the Manufacturing Industry: An Energy Economic Perspective. In Proceedings of the ASME 2015 International Manufacturing Science and Engineering Conference, Charlotte, NC, USA, 8-12 June 2015.

68. Chuang, S.; Sahoo, N.; Lin, H.W.; Chang, Y.H. Predictive Maintenance with Sensor Data Analytics on a Raspberry Pi-Based Experimental Platform. Sensors 2019, 19, 3884. [CrossRef]

69. Sreenivasan, R.; Goel, A.; Bourell, D.L. Sustainability issues in laser-based additive manufacturing. Phys. Procedia 2010, 5, 81-90. [CrossRef]

70. Rao, S.K.; Prasad, R. Impact of 5G technologies on industry 4.0. Wirel. Pers. Commun. 2018, 100, 145-159. [CrossRef] 
71. Shukla, S.; Mohanty, B.; Kumar, A. Strategizing sustainability in e-commerce channels for additive manufacturing using value-focused thinking and fuzzy cognitive maps. Ind. Manag. Data Syst. 2018, 118, 390-411. [CrossRef]

72. Fuel Energy Abstrarcts. 2007, 148, 394-448. Available online: https://www.sciencedirect.com/journal/fueland-energy-abstracts/vol/48/issue/6 (accessed on 5 April 2020).

73. Neal, A.D.; Sharpe, R.G.; Conway, P.P.; West, A.A. smaRTI-A cyber-physical intelligent container for industry 4.0 manufacturing. J. Manuf. Syst. 2019, 52, 63-75. [CrossRef]

74. Sheppard, P.; Rahimifard, S. Improving energy efficiency in manufacturing using peer benchmarking to influence machine design innovation. Clean Technol. Environ. Policy 2019, 21, 1213-1235. [CrossRef]

75. Shrouf, F.; Miragliotta, G. Energy management based on Internet of Things: Practices and framework for adoption in production management. J. Clean. Prod. 2015, 100, 235-246. [CrossRef]

76. Bhadra, A.; Kachwala, T. Impact of CSR on business. Int. J. Multidiscip. Manag. Stud. 2014, 4, $144-160$. Available online: http://www.indianjournals.com/ijor.aspx?target=ijor:xijmms\&volume=4\&issue=3\&article= 015 (accessed on 5 April 2020).

77. Zhang, T.C.; Jahromi, M.F.; Kizildag, M. Value co-creation in a sharing economy: The end of price wars? Int. J. Hosp. Manag. 2018, 71, 51-58. [CrossRef]

78. Xie, S.; Dai, H.N.; Zheng, Z.; Dai, H.; Chen, X.; Wang, H. An Overview of Blockchain Technology. Int. J. Adv. Res. Comput. Eng. Technol. 2018, 7, 789-795. [CrossRef]

79. Sikorski, J.J.; Haughton, J.; Kraft, M. Blockchain technology in the chemical industry: Machine-to-machine electricity market. Appl. Energy 2017, 195, 234-246. [CrossRef]

80. Gursel, A.P.; Masanet, E.; Horvath, A.; Stadel, A. Life-cycle inventory analysis of concrete production: A critical review. Cem. Concr. Compos. 2014, 51, 38-48. [CrossRef]

81. Altintas, K.; Tuğba, T.; Vayvay, Ö. Renewable energy for a sustainable future. Marmara Fen Bilimleri Derg. 2016, 28, 7-13. [CrossRef]

82. De La Torre, G.; Rad, P.; Choo, K.-K.R. Implementation of deep packet inspection in smart grids and industrial Internet of Things: Challenges and opportunities. J. Netw. Comput. Appl. 2019, 135, 32-46. [CrossRef]

83. Hannouf, M.; Assefa, G.; Gates, I. From social hotspots to policies for successful implementation of environmentally better technologies? The example of social life cycle assessment of oil and gas technologies in Alberta, Canada. Environ. Sci. Policy 2020, 110, 24-33. [CrossRef]

84. Sarkis, J.; Zhu, Q. Environmental sustainability and production: Taking the road less travelled. Int. J. Prod. Res. 2018, 56, 743-759. [CrossRef]

85. Junquera, B.; Barba-Sánchez, V. Environmental proactivity and firms' performance: Mediation effect of competitive advantages in Spanish wineries. Sustainability 2018, 10, 2155. [CrossRef]

86. Johansson, N.; Roth, E.; Reim, W. Smart and Sustainable eMaintenance: Capabilities for Digitalization of Maintenance. Sustainability 2019, 11, 3553. [CrossRef]

87. Khan, A.G. Electronic commerce: A study on benefits and challenges in an emerging economy. Glob. J. Manag. Bus. Res. 2016, 1-9. Available online: https://www.semanticscholar.org/paper/ElectronicCommerce\%3AStudy-on-Benefits-and-in-an-Khan/ccfdb3fed633c338362da7e0032256ff369936bf (accessed on 6 April 2020).

88. Terzi, N. The impact of e-commerce on international trade and employment. Procedia Soc. Behav. Sci. 2011, 24, 745-753. [CrossRef]

89. Mohelska, H.; Sokolova, M. Management approaches for Industry 4.0-the organizational culture perspective. Technol. Econ. Dev. Econ. 2018, 24, 2225-2240. [CrossRef]

90. Kulyk, V.; Škodová Parmová, D. E-business development: The comparative study of the Czech Republic and the Ukraine. Deturope 2017, 9, 80-110. Available online: http://www.deturope.eu/img/upload/content_ 95997736.pdf. (accessed on 6 April 2020).

91. Sullivan, Y.; Kim, D. Assessing the effects of consumers' product evaluations and trust on repurchase intention in e-commerce environments. Int. J. Inf. Manag. 2018, 39, 199-219. [CrossRef]

92. Santanen, E. The value of protecting privacy. Bus. Horiz. 2019, 62, 5-14. [CrossRef] 
93. Yaseen, H.; Alhusban, M.D.; Alhosban, A.; Dingley, K. Making Sense of E-Commerce Customers Awareness in a Developing Country Context: A Framework for Evaluation. Electron. J. Inf. Syst. Eval. 2017, 20, 102-115. Available online: https://www.researchgate.net/publication/319332735_Making_Sense_of_ECommerce_Customers_Awareness_in_a_Developing_Country_Context_A_Framework_for_Evaluation (accessed on 6 April 2020).

94. Stock, T.; Seliger, G. Opportunities of sustainable manufacturing in industry 4.0. Procedia Cirp 2016, 40, 536-541. [CrossRef]

95. Brous, P.; Janssen, M.; Herder, P. The dual effects of the Internet of Things (IoT): A systematic review of the benefits and risks of IoT adoption by organizations. Int. J. Inf. Manag. 2020, 51, 101952. [CrossRef]

96. Wang, S.; Wan, J.; Li, D.; Zhang, C. Implementing Smart Factory of Industrie 4.0: An Outlook. Int. J. Distrib. Sens. Netw. 2016, 12, 3159805. Available online: http://journals.sagepub.com/doi/10.1155/2016/3159805 (accessed on 5 April 2020). [CrossRef]

97. Lu, Y. Industry 4.0: A survey on technologies, applications and open research issues. J. Ind. Inf. Integr. 2017, 6,1-10. [CrossRef]

98. Goni, F.A.; Shukor, S.A.; Mukhtar, M.; Sahran, S. Environmental sustainability: Research growth and trends. Adv. Sci. Lett. 2015, 21, 192-195. [CrossRef]

99. Gielen, D.; Boshell, F.; Saygin, D.; Bazilian, M.D.; Wagner, N.; Gorini, R. The role of renewable energy in the global energy transformation. Energy Strategy Rev. 2019, 24, 38-50. [CrossRef]

100. Griggs, D.; Smith, M.S.; Rockström, J.; Öhman, M.C.; Gaffney, O.; Glaser, G.; Kanie, N.; Noble, I.; Steffen, W.; Shyamsundar, P. An integrated framework for sustainable development goals. Ecol. Soc. 2014, 19. Available online: https://www.jstor.org/stable/26269703?seq=1\#metadata_info_tab_contents (accessed on 5 April 2020). [CrossRef]

101. Goodland, R.; Daly, H. Environmental sustainability: Universal and non-negotiable. Ecol. Appl. 1996, 6, 1002-1017. [CrossRef]

102. Habbard, G. Measuring organization performance beyond the triple button line. Bus Strateg. 2009, 177-191. [CrossRef]

103. Qin, J.; Liu, Y.; Grosvenor, R. A categorical framework of manufacturing for industry 4.0 and beyond. Procedia Cirp 2016, 52, 173-178. [CrossRef]

104. Li, G.; Wang, H.; Hardjawana, W. New advancement in information technologies for industry 4.0. Enterp. Inf. Syst. 2020, 14, 402-405. [CrossRef]

105. Dorofeev, K.; Cheng, C.-H.; Guedes, M.; Ferreira, P.; Profanter, S.; Zoitl, A. Device Adapter Concept Towards Enabling Plug\&Produce Production Environments. In Proceedings of the 2017 22nd IEEE International Conference on Emerging Technologies and Factory Automation (ETFA), Limassol, Cyprus, 12-15 September 2017; pp. 1-8.

106. Nagy, S. E-commerce in Hungary: A Market Analysis. Theory Methodol. Pract. 2016, 12, 25-32. [CrossRef]

107. Luchs, M.G.; Phipps, M.; Hill, T. Exploring consumer responsibility for sustainable consumption. J. Mark. Manag. 2015, 31, 1449-1471. [CrossRef]

108. Sima, V.; Gheorghe, I.G.; Subić, J.; Nancu, D. Influences of the Industry 4.0 Revolution on the Human Capital Development and Consumer Behavior: A Systematic Review. Sustainability 2020, 12, 4035. [CrossRef]

109. Lee, J.; Bagheri, B. A cyber-physical systems architecture for industry. Manuf. Lett. 2015, 3, 18-23. [CrossRef]

110. Sogari, G.; Pucci, T.; Aquilani, B.; Zanni, L. Millennial generation and environmental sustainability: The role of social media in the consumer purchasing behavior for wine. Sustainability 2017, 9, 1911. [CrossRef]

111. Drath, R.; Horch, A. Industrie 4.0: Hit or hype? IEEE Ind. Electron. Mag. 2014, 8, 56-58. [CrossRef]

112. Kabugo, J.C.; Jämsä-Jounela, S.-L.; Schiemann, R.; Binder, C. Industry 4.0 based process data analytics platform: A waste-to-energy plant case study. Int. J. Electr. Power Energy Syst. 2020, 115, 1-17. [CrossRef]

113. Chen, H.; Zhang, M.; Xue, K.; Xu, G.; Yang, Y.; Wang, Z.; Liu, W.; Liu, T. An innovative waste-to-energy system integrated with a coal-fired power plant. Energy 2020, 194, 1-17. [CrossRef]

114. D'Adamo, I.; Falcone, P.M.; Ferella, F. A socio-economic analysis of biomethane in the transport sector: The case of Italy. Waste Manag. 2019, 95, 102-115. [CrossRef] 
115. Falcone, P.M.; Lopolito, A.; Sica, E. Instrument mix for energy transition: A method for policy formulation. Technol. Forecast. Soc. Chang. 2019, 148, 119706. [CrossRef]

116. Benitez, G.B.; Ayala, N.F.; Frank, A.G. Industry 4.0 innovation ecosystems: An evolutionary perspective on value cocreation. Int. J. Prod. Econ. 2020, 228, 1-13. [CrossRef]

(c)

(C) 2020 by the authors. Licensee MDPI, Basel, Switzerland. This article is an open access article distributed under the terms and conditions of the Creative Commons Attribution (CC BY) license (http://creativecommons.org/licenses/by/4.0/). 